\title{
AKTIVITAS ANTIOKSIDAN, KADAR PATI RESISTEN, DAN ORGANOLEPTIK ES KRIM PISANG BATU (Musa Balbisiana Colla) SEBAGAI MAKANAN FUNGSIONAL UNTUK PENCEGAHAN PENYAKIT KANKER KOLOREKTAL
}

\author{
Almuthya Ahsin, Hartanti Sandi Wijayanti, Diana Nur Afifah* \\ Departemen Ilmu Gizi, Fakultas Kedokteran, Universitas Diponegoro \\ Jl. Prof. Sudarto SH, Tembalang, Semarang, Jawa Tengah 50275, Indonesia \\ *Penulis Penanggungjawab. E-mail: diananurafifah@live.undip.ac.id
}

\begin{abstract}
Background: Colorectal cancer can be caused excessive production of free radicals or lack of antioxidants in the body. The content of resistant starch and antioxidant activity in pisang batu can provide prevention of colorectal cancer. The aimed of this study was to analyze antioxidant activity content, resistant starch levels and organoleptic pisang batu ice cream as a functional food for the prevention of colorectal cancer.

Methods: This study used experimental method with two factor including pisang batu content, which is $12 \%$ and $17 \%$ and variations during cooking and cooling process. Analysis of antioxidant activity used the DPPH method and resistant starch levels used the method of Kim et al. Statistical analysis of antioxidant activity and resistant starch levels used One Way Anova, Kruskall-Wallis and Tukey test. Organoleptic analysis is used Kruskall-Wallis test and Mann Withney.

Results: Ice cream with the highest antioxidant activity was found in ice cream with the addition of $17 \%$ pisang batu flour and added during cooling process. The levels of resistant starch did not show a statistical difference, even though the highest levels of resistant starch was found added during cooking process. There was a significant difference in the organoleptic test of aroma and taste with the most preferred ice cream with a level of $12 \%$ for aroma and for taste is added when cooling process.

Conclusion: an increase in the addition of banana stone flour levels and the addition when cooling process results in higher antioxidant activity.
\end{abstract}

Keywords: Batu Banana Flour; Colorectal Cancer; Antioxidant Activity; Resistant Starch Levels

\begin{abstract}
ABSTRAK
Latar Belakang: Kanker kolorektal dapat disebabkan karena berlebihnya produksi radikal bebas atau kurangnya antioksidan dalam tubuh. Kandungan pati resisten dan aktivitas antioksidan pada pisang batu dapat memberikan pencegahan penyakit kanker kolorektal.

Tujuan: Penelitian ini bertujuan untuk menganalisis kandungan aktivitas antioksidan, kadar pati resisten dan organoleptik es krim pisang batu sebagai makanan fungsional untuk pencegahan penyakit kanker kolorektal.

Metode: Penelitian eksperimental acak lengkap dua faktor meliputi kadar tepung pisang batu, yaitu $12 \%$ dan $17 \%$ serta variasi cara penambahan, yaitu pada saat pemasakan dan pendinginan. Analisis aktivitas antioksidan menggunakan metode DPPH dan kadar pati resisten menggunakan metode Kim et al. Analisis statistik aktivitas antioksidan dan kadar pati resisten menggunakan uji one way Anova, Kruskall-Wallis dan tukey. Analisis organoleptik menggunakan uji Kruskall-Wallis dan mann withney.

Hasil: Aktivitas antioksidan tertinggi didapatkan pada es krim dengan penambahan tepung pisang batu $17 \%$ dan yang ditambahkan ketika pendinginan. Kadar pati resisten tidak menunjukkan beda secara statistik, walaupun didapatkan kadar pati resisten lebih tinggi yang ditambahkan ketika pemasakan. Terdapat perbedaan signifikan pada uji organoleptik aroma dan rasa dengan yang paling disukai es krim dengan kadar $12 \%$ untuk aroma dan es krim dengan cara penambahan saat pendinginan untuk rasa.

Simpulan: Terjadi peningkatan aktivitas antioksidan seiring banyaknya tepung pisang batu yang digunakan dan ditambahkan ketika proses pendinginan. Produk terbaik yang direkomendasikan adalah es krim yang diberikan tepung pisang batu dengan kadar $17 \%$ dan ditambahkan saat pendinginan.
\end{abstract}

Kata Kunci: Tepung Pisang batu; Kanker kolorektal; Aktivitas Antioksidan; Pati rsisten

\section{PENDAHULUAN}

Kanker kolorektal merupakan penyakit keganasan ketiga terbanyak di dunia dan penyebab kematian kedua terbanyak di Amerika. ${ }^{1}$ Pada tahun 2015, insiden kanker kolorektal di Indonesia adalah
12,8 per 100.000 penduduk usia dewasa dan jumlah penderita kanker kolorektal sudah mencapai $10 \%$ dari semua jenis kanker atau sekitar 1,4 juta orang menderita penyakit tersebut. ${ }^{2}$ Tingginya angka ini dapat diakibatkan oleh perubahan pada diet orang 
indonesia, baik sebagai konsekuensi peningkatan kemakmuran maupun pergeseran ke arah cara makan orang barat yang lebih tinggi lemak serta rendah serat.

Kanker kolorektal adalah tumor yang berasal dari jaringan usus besar hingga kolon. Tingginya konsumsi lemak dan rendahnya konsumsi serat merupakan salah satu faktor risiko penyebab terjadinya kanker kolorektal. Hipotesis suatu studi menjelaskan bahwa risiko kanker kolon ditentukan dari interaksi antara diet dan mikrobiota. Tingginya kejadian risiko pada kelompok Afrika-Amerika dapat dikarenakan konsumsi serat dan pati resisten yang rendah serta tingginya konsumsi lemak. ${ }^{2}$

Pati resisten merupakan fraksi pati atau produk degradasi pati yang tidak terabsorpsi di dalam usus halus dan memiliki sifat resisten oleh hidralisis enzim pencernaan. ${ }^{3,4}$ Pati resisten yang tidak diabsropsi langsung menuju usus besar dan akan difermentasi oleh mikroflora di dalamnya., Fermentasi pati resisten dapat meningkatkan konsentrasi dari asam lemak pendek / Short Chain Fatty Acid (SCFA) khususnya asam butirat yang merupakan energi bagi sel kolorektal dan mampu menghambat sel kanker karena dapat menghambat terjadinya poliferasi sel kanker kolorektal dan menginduksi apoptosis. ${ }^{6,7}$

Zat gizi lainya yang mempunyai hubungan yang menguntungkan terhadap penurunan risiko kanker kolorektal adalah antioksidan. Antioksidan diperlukan untuk mencegah stres oksidatif. Stres oksidatif adalah kondisi ketidakseimbangan antara jumlah radikal bebas yang ada dengan jumlah antioksidan di dalam tubuh. Stres oksidatif berperan penting dalam patofisiologi terjadinya proses penuaan dan berbagai penyakit degeneratif, seperti kanker. Radikal bebas merupakan senyawa yang mengandung satu atau lebih elektron tidak berpasangan dalam orbitalnya, sehingga bersifat sangat reaktif dan mampu mengoksidasi molekul di sekitarnya. Antioksidan bersifat sangat mudah dioksidasi, sehingga radikal bebas akan mengoksidasi antioksidan dan melindungi molekul lain dalam sel dari kerusakan akibat oksidasi oleh radikal. ${ }^{8}$

Kandungan pati resisten diantaranya dapat ditemukan pada kentang, pisang, dan beras. Pemilihan pisang sebagai bahan baku pada penelitian ini disebabkan karena pisang merupakan tanaman pangan hortikultura yang banyak ditemukan di daerah dengan iklim tropis, salah satunya di Indonesia. Berdasarkan penelitian dari berbagai varietas pisang, pisang batu (Musa balbisiana colla) memiliki kandungan pati resisten yang paling tinggi yaitu $39,50 \% .^{9}$ Selain itu, pisang juga memiliki aktivitas antioksidan yang cukup tinggi, yaitu $41,2 \mu \mathrm{g} / \mathrm{mL} . \quad \beta$ carotene, dan asam askorbat adalah jenis antioksidan yang terdapat pada pisang. ${ }^{10}$ Aktivitas antioksidan yang terdapat pada pisang berbeda-beda tergantung bagiannya. Berdasarkan uji antioksidan menggunakan metode DPPH pada pisang batu, bagian biji memiliki aktivitas paling tinggi. ${ }^{11}$

Salah satu bentuk pangan fungsional yang dikenal masyarakat adalah es krim. Pemilihan es krim sebagai produk olahan tepung pisang batu dikarenakan makanan ini merupakan salah satu produk makanan yang sangat disukai oleh masyarakat pada segala kelompok usia. Faktor utama yang berkontribusi dalam peningkatan konsumsi es krim adalah kondisi cuaca di Indonesia yang cukup panas, pertumbuhan jumlah penduduk yang diikuti dengan peningkatan daya beli, dan tingginya persentase kelompok usia muda. ${ }^{12}$ Pembuatan es krim dalam metode konvensional utamanya meliputi 4 tahap, yaitu pemasakan, pendinginan I, pengadonan, pendinginan II.

Penambahan tepung pisang batu dapat meningkatkan aktivitas antioksidan pada es krim pisang batu. Namun cara yang dilakukan ketika penambahan tepung pisang batu juga dapat menurunkan aktivitas antioksidan. Oleh karena itu pada penelitian ini peneliti melakukan dua variasi cara penambahan tepung pisang batu yaitu, ketika proses pemasakan dan pendinginan. Menurut penelitian sebelumnya, proses pengolahan yang meminimalisir pemanasan dan penyimpanan suhu dingin terbukti dapat membantu menjaga aktivitas antioksidan. ${ }^{13}$

Pada penelitian sebelumnya, telah dilakukan penelitian untuk melihat bagaimana kandungan dan karakteristik pati resisten pada berbagai varietas tepung pisang dimana hasilnya menunjukkan bahwa pisang batu memiliki kadar pati resisten paling tinggi. ${ }^{9}$ Namun belum terdapat penelitian yang melakukan pengolahan produk makanan dari tepung pisang batu sehingga pada penelitian ini peneliti bertujuan untuk mengetahui kandungan aktivitas antioksidan, kadar pati resisten, organoleptik es krim pisang batu (Musa balbisiana colla) sebagai makanan fungsional untuk pencegahan penyakit kanker kolorektal.

\section{METODE}

Penelitian ini termasuk dalam ruang lingkup keilmuan teknologi pangan/food production. Pelaksanaan dilakukan dalam rentang waktu Juni Juli 2018 di Laboratorium Terpadu Universitas Diponegoro. Sampel pada penelitian menggunakan pisang batu yang diperoleh dari Wonosobo. Karakteristik pisang batu yang digunakan adalah pisang batu yang berumur 60-70 hari, memiliki warna kulit hijau agak kekuningan. Pisang batu tersebut diolah menjadi tepung dengan cara dipotong kecil, dikeringkan lalu diblender halus kemudian diayak 
menggunakan ayakan 80 mesh sehingga menghasilkan tepung pisang batu. Selanjutnya tepung pisang batu diolah menjadi es krim yang meliputi 4 tahap utama, yaitu pemasakan, pendinginan I, dan pendinginan II.

Dalam penelitian ini dilakukan formulasi perlakuan berupa substitusi tepung pisang batu dengan susu bubuk. Terdapat dua komposisi tepung pisang batu yaitu $12 \%$ dan $17 \%$ serta dua variasi cara penambahan yaitu sebelum pemasakan dan setelah pendinginan I. Komposisi awal es krim yang digunakan adalah susu bubuk, SP, air putih, gula, maizena,dan garam. Substitusi tepung pisang batu dengan dua komposisi tersebut diperoleh dari penelitian pendahuluan bahwa substitusi terhadap susu bubuk maksimal 17\%. Persentase komposisi tersebut diperoleh dengan mempertimbangkan uji penerimaan berdasarkan warna, aroma, rasa, dan tekstur sehingga diperoleh perlakuan pada Tabel 1 .

Tabel 1. Komposisi Bahan Es Krim Pisang Batu

\begin{tabular}{lcc}
\hline \multicolumn{1}{c}{ Bahan } & $\mathbf{1 2 \%}$ & $\mathbf{1 7 \%}$ \\
\hline Tepung pisang batu (\%) & 12 & 17 \\
Susu bubuk (\%) & 12 & 7 \\
SP (\%) & 2 & 2 \\
Air (\%) & 55 & 55 \\
Gula (\%) & 10 & 10 \\
Maizena (\%) & 2 & 2 \\
Garam $(\%)$ & 0,4 & 0,4 \\
\hline
\end{tabular}

Penetapan kadar tepung pisang batu didasPada penelitian ini terdapat 4 kelompok perlakuan, yaitu es krim pisang batu menggunakan tepung pisang batu $12 \%$ dengan waktu penambahan tepung saat pemasakan (AI), es krim pisang batu menggunakan tepung pisang batu $12 \%$ dengan waktu penambahan tepung saat pendinginan (AII), es krim pisang batu menggunakan tepung pisang batu $17 \%$ dengan waktu penambahan tepung saat pemasakan (BI) dan es krim pisang batu menggunakan tepung pisang batu $17 \%$ dengan waktu penambahan tepung saat pendinginan (BII).

Data yang dikumpulkan pada penelitian ini adalah aktivitas antioksidan, kadar pati resisten, dan daya terima es krim tepung pisang batu. Uji antioksidan menggunakan metode DPPH yang akan menunjukkan hasil total aktivitas antioksidan di dalam es krim. Uji kadar pati resisten metode Kim et $a l$, dan uji daya terima menggunakan uji hedonik yang dinilai oleh 30 panelis agak terlatih yaitu Mahasiswa Ilmu Gizi FK Undip. Atribut mutu makanan yang diuji berupa warna, aroma, rasa, dan tekstur pada keempat perlakuan. Penilaian atribut mutu menggunakan 4 skala kesukaan yaitu, 1-1,5 (sangat tidak suka), 1,6-2,5 (Tidak suka), 2,6-3,5 (Suka), dan 3,6-4,5 (sangat suka).
Perlakuan terbaik dipilih berdasarkan indeks efektivitas menggunakan metode de Garmo yang dimodifikasi oleh Susrini. Penentuan perlakuan terbaik dimulai dengan memberikan bobot variabel (BV) dari angka 0 - 1 pada masing-masing parameter berdasarkan tingkat kepentingannya. Semakin tinggi tingkat kepentingan, semakin tinggi nilai bobot variabel yang diberikan. Variabel dari segi gizi dan mutu organoleptik diberikan bobot yang sama oleh peneliti. Bobot normal (BN) kemudian ditentukan pada setiap parameter dari pembagian bobot variabel per perlakuan dengan jumlah bobot variabel semua perlakuan. Setelah itu, nilai efektivitas $(\mathrm{Ne})$ diperoleh dengan membandingkan selisih nilai perlakuan (NP) dan nilai terburuk dengan selisih nilai terbaik dan terburuk. Nilai hasil (Nh) merupakan nilai akhir masing-masing parameter yang ditentukan dari hasil perkalian nilai efektivitas dengan bobot normal, selanjutnya nilai hasil dari masing-masing perlakuan dijumlahkan. Perlakuan dengan total nilai hasil tertinggi dianggap sebagai perlakuan terbaik yang direkomendasikan dalam penelitian ini. ${ }^{14}$

Analisis data dilakukan menggunakan program komputer yang sebelumnya diuji normalitas menggunakan uji Shapiro-Wilk. Kandungan aktivitas antioksidan dan kadar pati resisten antar perlakuan dianalisis menggunakan uji One-way anova untuk data yang berdistribusi normal dan uji KruskallWallis untuk data yang berdistribusi tidak normal dilanjutkan dengan uji lanjut Tukey untuk mengetahui beda nyata antar perlakuan. Data uji organoleptik dianalisis menggunakan uji Kruskall-Wallis dan dilanjutkan dengan uji lanjut Mann-Whitney untuk mengetahui beda nyata antar perlakuan.

\section{HASIL}

\section{Aktivitas antioksidan dan kadar pati resisten}

Es krim tepung pisang batu dengan berbagai perlakuan dianalisis aktivitas antioksidannya sehingga diperoleh hasil seperti pada Tabel 2 .

Tabel 2. Hasil Rerata Aktivitas Antioksidan dan Kadar Pati Resisten Antar Perlakuan

\begin{tabular}{|c|c|c|}
\hline \multirow[t]{2}{*}{ Perlakuan } & $\begin{array}{l}\text { Kadar } \\
\text { Antioksidan }\end{array}$ & $\begin{array}{l}\text { Kadar Pati } \\
\text { resisten }\end{array}$ \\
\hline & $\operatorname{Rerata}(\%) \pm \mathrm{SB}$ & $\operatorname{Rerata}(\%) \pm \mathrm{SB}$ \\
\hline AI & $15,96 \pm 0,15^{\mathrm{a}}$ & $12,00 \pm 2,82$ \\
\hline AII & $16,90 \pm 2,94^{\mathrm{a}}$ & $9,33 \pm 1,15$ \\
\hline BI & $24,60 \pm 0,10^{\mathrm{b}}$ & $12,00 \pm 2,00$ \\
\hline BII & $29,10 \pm 1,90^{\mathrm{b}}$ & $11,33 \pm 1,15$ \\
\hline$P$ & $<0,01^{*}$ & $<0,27^{* *}$ \\
\hline
\end{tabular}
one way ANOVA; ${ }^{* *}$ pengujian dengan kruskal wallis 
Berdasarkan Tabel 2 hasil uji statistik menunjukkan terdapat perbedaan aktivitas antioksidan antara kelompok perlakuan. Akan tetapi, setelah dilakukan uji lanjut kelompok perlakuan yang diberikan variasi cara penambahan tidak menujukkan perbedaan yang signifikan secara statistik, meskipun apabila dilihat dari rerata hasil uji menunjukkan terdapatnya peningkatan aktivitas antioksidan yang ditambahkan ketika pendinginan.
Berdasarkan Tabel 2 dapat dilihat juga bahwa hasil uji statistik menunjukkan tidak terdapat perbedaan yang signifikan pada penambahan tepung pisang batu terhadap kadar pati resisten $(p=0,27)$, meskipun apabila dilihat dari rerata hasil uji menunjukkan terdapatnya peningkatan kadar pati resisten pada kelompok perlakuan yang ditambahkan ketika pemasakan.

Tabel 3. Hasil Uji Organoleptik Es Krim Pisang Batu

\begin{tabular}{lllllllll}
\hline & Warna & & Aroma & & Rasa & \multicolumn{2}{c}{ Tekstur } \\
\cline { 2 - 8 } Perlakuan & Rerata \pm SB & Kategori & Rerata \pm SB & Kategori & Rerata \pm SB & Kategori & Rerata \pm SB & Kategori \\
\hline AI & $3,13 \pm 0,77$ & Suka & $3,13 \pm 0,62^{\text {a }}$ & Suka & $2,93 \pm 0,74^{\mathrm{a}}$ & Suka & $2,23 \pm 0,81$ & Tidak suka \\
AII & $3,40 \pm 0,67$ & Suka & $3,10 \pm 0,30^{\mathrm{a}}$ & Suka & $3,17 \pm 0,46^{\mathrm{a}}$ & Suka & $2,23 \pm 0,81$ & Tidak suka \\
BI & $3,03 \pm 0,49$ & Suka & $2,60 \pm 0,57^{\mathrm{b}}$ & Suka & $2,62 \pm 0,65^{\mathrm{b}}$ & Suka & $2,63 \pm 0,66$ & Suka \\
BII & $3,17 \pm 0,64$ & Suka & $3,07 \pm 0,52^{\mathrm{a}}$ & Suka & $3,17 \pm 0,59^{\mathrm{a}}$ & Suka & $2,40 \pm 0,67$ & Tidak Suka \\
\hline$p^{*}$ & 0,09 & & $<0,01$ & & $<0,01$ & & 0,15 & \\
\hline
\end{tabular}

Keterangan : Nilai pada satu baris yang diikuti huruf superscript berbeda (a,b,c,d) menunjukkan beda nyata (p<0.05) dengan uji Mann Withney, * pengujian dengan Uji Kruskal Wallis

Tabel 4. Pembobotan Total Aktivitas Antioksidan, Kadar Pati Resisten Dan Uji Organoleptik.

\begin{tabular}{|c|c|c|c|c|c|c|c|c|}
\hline \multirow{2}{*}{ Variabel } & \multirow{2}{*}{ BV } & \multirow{2}{*}{$\mathbf{B N}$} & \multicolumn{4}{|c|}{$\mathbf{N p}$} & \multirow{2}{*}{$\begin{array}{c}\text { Nilai } \\
\text { terbaik }\end{array}$} & \multirow{2}{*}{$\begin{array}{c}\text { Nilai } \\
\text { terburuk }\end{array}$} \\
\hline & & & AI & AII & BI & BII & & \\
\hline Antioksidan & 1 & 0,250 & 15,96 & 16,90 & 24,60 & 29,10 & 29,10 & 15,96 \\
\hline Pati resisten & 1 & 0,250 & 12,00 & 9,33 & 12,00 & 11,33 & 12,00 & 9,33 \\
\hline Warna & 0,5 & 0,125 & 3,13 & 3,40 & 3,03 & 3,17 & 3,40 & 3,03 \\
\hline Aroma & 0,5 & 0,125 & 3,13 & 3,10 & 2,60 & 3,07 & 3,13 & 2,60 \\
\hline Rasa & 0,5 & 0,125 & 2,93 & 3,17 & 2,62 & 3,17 & 3,17 & 2,62 \\
\hline Tekstur & 0,5 & 0,125 & 2,23 & 2,23 & 2,63 & 2,40 & 2,63 & 2,23 \\
\hline
\end{tabular}

Keterangan: Kadar 12\% ditambahkan saat pemasakan (AI), kadar 12\% ditambahkan saat pendinginan (AII), kadar 17\% ditambahkan saat pemasakan (BI), kadar 17\% ditambahkan saat pendinginan (BII), bobot variabel (BV), bobot normal (BN), nilai perlakuan (NP).

Tabel 5. Skor Penentuan Perlakuan Terbaik

\begin{tabular}{|c|c|c|c|c|c|c|c|c|c|}
\hline \multirow{2}{*}{ Variabel } & \multirow{2}{*}{$\begin{array}{c}\text { Selisih nilai } \\
\text { terbaik dan } \\
\text { terburuk }\end{array}$} & \multicolumn{2}{|c|}{ AI } & \multicolumn{2}{|c|}{ AII } & \multicolumn{2}{|c|}{ BI } & \multicolumn{2}{|c|}{ BII } \\
\hline & & $\mathrm{Ne}$ & Nh & $\mathrm{Ne}$ & Nh & $\mathrm{Ne}$ & Nh & $\mathrm{Ne}$ & Nh \\
\hline Antioksidan & 13,14 & 0,000 & 0,000 & 0,071 & 0,017 & 0,657 & 0,164 & 1,000 & 0,250 \\
\hline Pati resisten & 2,67 & 1,000 & 0,250 & 0,000 & 0,000 & 1,000 & 0,250 & 0,749 & 0,186 \\
\hline Warna & 0,37 & 0,270 & 0,033 & 1,000 & 0,125 & 0,000 & 0,000 & 0,378 & 0,047 \\
\hline Aroma & 0,53 & 1,000 & 0,125 & 0,943 & 0,117 & 0,000 & 0,000 & 0,886 & 0,110 \\
\hline Rasa & 0,55 & 0,563 & 0,070 & 1,000 & 0,125 & 0,000 & 0,000 & 1,000 & 0,125 \\
\hline Tekstur & 0,4 & 0,000 & 0,000 & 0,000 & 0,000 & 1,000 & 0,125 & 0,425 & 0,053 \\
\hline Total & & & 0,478 & & 0,384 & & 0,539 & & 0,771 \\
\hline
\end{tabular}

Keterangan: Kadar 12\% ditambahkan saat pemasakan (AI), kadar 12\% ditambahkan saat pendinginan (AII), kadar 17\% ditambahkan saat pemasakan (BI), kadar $17 \%$ ditambahkan saat pendinginan (BII), nilai efektifitas (Ne), nilai hasil (Nh).

\section{Organoleptik}

Berdasarkan Tabel 3 didapatkan hasil bahwa tidak terdapat perbedaan pada atribut warna dan tekstur antara perlakuan AI, AII, BI, dan BII. Menurut panelis warna keempat perlakuan dapat diterima, cukup cerah, bagus serta menarik. Namun, apabila dilihat dari rerata sebagian besar panelis lebih menyukai warna perlakuan AII. Pada atribut tekstur, panelis paling menyukai tekstur dari kelompok perlakuan yang diberikan kadar tepung pisang $17 \%$ karena dianggap hampir menyerupai tekstur es krim komersial, dalam hal ini tingkat kepadatan, kelembutan dan memiliki tekstur granula yang banyak seperti taburan oreo.

Penilaian terhadap atribut rasa dan aroma didapatkan perbedaan yang signifikan antara perlakuan AI, AII, BI, dan BII. Panelis menyukai rasa keempat perlakuan. Tetapi setelah dilakukan uji lanjut diketahui bahwa perlakuan yang paling disukai panelis adalah ketika tepung pisang batu ditambahkan 
saat pendinginan. Pada atribut aroma, keempat perlakuan yang diuji dapat diterima. Namun berdasarkan hasil dari uji lanjut didapatkan bahwa panelis paling menyukai aroma kelompok perlakuan yang diberikan penambahan tepung pisang batu sebanyak $12 \%$.

\section{Perlakuan Terbaik}

Hasil analisis penentuan perilaku terbaik menunjukkan bahwa nilai hasil (Nh) tertinggi diperoleh perlakuan es krim dengan penambahan tepung pisang batu dengan kadar $17 \%$ dan ditambahkan saat pendinginan dengan nilai sebesar 0,771 . Nilai hasil $(\mathrm{Nh})$ terendah diperoleh perlakuan es krim yang diberikan tepung pisang batu dengan kadar $12 \%$ yang ditambahkan saat pendinginan. Perlakuan terbaik dengan mempertimbangkan nilai total aktivitas antioksidan, kadar pati resisten dan uji organoleptik yaitu perlakuan es krim dengan penambahan tepung pisang batu dengan kadar $17 \%$ dan ditambahkan saat pendinginan (BII). Perlakuan BII mempunyai total aktivitas antioksidan $29,10 \%$, kadar pati resisten $11,33 \%$ dan cukup disukai panelis berdasarkan penerimaan aroma, warna, rasa walaupun kurang disukai panelis berdasarkan penerimaan tekstur.

\section{PEMBAHASAN}

Hasil analisis aktivitas antioksidan menunjukkan terdapat perbedaan yang signifikan aktivitas antioksidan pada kelompok perlakuan. Setelah dilakukan uji lanjut, perbedaan yang signifikan didapatkan pada kelompok perlakuan yang diberikan kadar tepung pisang batu yang berbeda. Pada kelompok perlakuan yang diberikan variasi cara penambahan tepung pisang batu tidak menunjukkan perbedaan yang signifikan secara statistik, meskipun apabila dilihat dari rerata hasil uji menunjukkan terdapatnya peningkatan aktivitas antioksidan yang ditambahkan saat pendinginan.

Pada kelompok perlakuan A dan B masingmasing perlakuan diberikan kadar tepung pisang batu yang berbeda yaitu $12 \%$ dan $17 \%$. Kadar antioksidan tertinggi didapatkan pada kelompok perlakuan B. Hal ini menunjukkan bahwa aktivitas antioksidan dapat terus meningkat seiring bertambahnya tepung pisang batu yang digunakan. Pisang merupakan salah satu sumber antioksidan alami yang memiliki aktivitas antioksidan yang tergolong cukup tinggi, yaitu 41,2 $\mu \mathrm{g} / \mathrm{mL} .{ }^{10}$ Jenis antioksidan yang terkandung di dalam pisang adalah $\beta$-karoten dan asam askorbat. ${ }^{10}$ Kedua antioksidan ini digolongkan kedalam antioksidan sekunder yang biasa disebut juga antioksidan eksogeneus atau non enzimatis. Antioksidan ini menghambat pembentukan senyawa oksigen reaktif dari radikal bebas dengan cara pengelatan metal, atau dirusak pembentukannya. Target utama dari radikal bebas adalah protein, asam lemak tak jenuh, dan lipoprotein. Senyawa radikal bebas di dalam tubuh dapat merusak asam lemak tak jenuh ganda pada membaran sel. Akibatnya, dinding sel menjadi rapuh. Senyawa oksigen reaktif ini mampu meruksak bagian dalam pembuluh darah sehingga meningkatnya pengendapan kolestrol dan menimbulkan aterosklerosis. Jaringan lipid juga akan dirusak oleh senyawa radikal bebas sehingga terbentuk peroksida yang memicu munculnya penyakit degeneratif, seperti kanker kolorektal.

Prinsip kerja sistem antioksidan non enzimatis yaitu dengan cara memotong reaksi oksidasi berantai dari radikal bebas atau dengan menangkap radikal tersebut, sehingga radikal bebas tidak akan bereaksi dengan komponen seluler. ${ }^{8} \mathrm{Hal}$ tersebut menunjukkan bahwa $\beta$-karoten dan asam askorbat dapat menjadi antioksidan alami, namun belum terdapat informasi mengenai ketersediaan kapasitas antioksidan dalam $\beta$-karoten dan asam askorbat.

Variasi penambahan tepung tidak menunjukkan perbedaan aktivitas antioksidan yang signifikan secara statistik, walaupun secara rerata didapatkan bahwa penambahan ketika pendinginan memiliki aktivitas antioksidan yang lebih tinggi dibandingkan saat pemasakan. Berdasarkan penelitian diketahui bahwa antioksidan memiliki sensitivitas terhadap suhu panas sehingga dapat menyebabkan senyawa flavonoid tersebut mengalami degradasi kimia sehingga dapat menurunkan aktivitas antioksidan selama proses pemanasan. ${ }^{15}$

Suatu bahan dapat dikatakan aktif sebagai antioksidan bila presentase aktivitas antioksidan lebih atau sama dengan 50\%. Dari hasil uji aktivitas antioksidan pada semua sampel perlakuan didapatkan bahwa aktivitas antioksidannya kurang dari $50 \%$. Rendahnya persentase angka antioksidan ini disebabkan oleh sedikitnya penggunaan tepung pisang batu dan susu sehingga tidak dapat menghasilkan produk dengan aktivitas antioksidan yang tinggi. ${ }^{22}$

Menurut Goni dkk, klasifikasi bahan makanan yang mengandung pati resisten dibagi menjadi lima golongan, antara lain : (a) sangat rendah (<1\%), (b) rendah $(1-2,5 \%)$, (c) sedang $(2,5-5 \%)$, (d) tinggi $(5-15 \%)$ dan (e) sangat tinggi $(>15 \%){ }^{23}$ Hasil uji kandungan kadar pati resisten pada semua sampel perlakuan es krim pisang batu menunjukkan bahwa kadar pati resisten lebih dari 5\%. Analisis statistik pada pati resisten menunjukkan hasil tidak terdapat perbedaan yang signifikan pada penambahan tepung pisang batu terhadap kadar pati resisten baik itu pada kelompok perlakuan variasi kadar maupun variasi cara penambahan tepung pisang batu, meskipun apabila dilihat dari rerata hasil uji 
menunjukkan terdapatnya peningkatan kadar pati resisten pada perlakuan es krim dengan penambahkan tepung pisang batu $17 \%$ dan ditambahkan ketika proses pemasakan.

Peningkatan rerata angka persen pati resisten pada kelompok perlakuan perlakuan es krim dengan penambahkan tepung pisang batu $17 \%$ disebabkan karena pisang batu merupakan sumber pati resisten yang cukup tinggi. Salah satu komposisi kimia pada pisang batu yaitu kadar amilopektin sangat berpengaruh pada kandungan pati resisten. Semakin tinggi kandungan amilopektin maka pati akan semakin sulit (resisten) untuk dicerna sehingga kadar pati resisten akan semakin tinggi. Menurut penelitian laju hidrolisis oleh enzim alfa amilase akan lebih cepat pada rantai lurus (amilosa) dibandingkan pada rantai yang bercabang (amilopektin). Proses pemasakan atau pemanasan pati yang disertai dengan air akan mengakibatkan pati mengalami gelatinisasi, suatu proses yang meliputi hidrasi dan pelarutan granula pati. Selain itu proses pendinginan pati yang telah tergelatinisasi dapat mengubah struktur pati menjadi kristal baru yang tidak larut berupa pati teretrogradasi. Sehingga dapat meningkatkan kadar pati resisten. ${ }^{19}$

Hasil analisis statistik menunjukkan bahwa terdapat perbedaan yang signifikan uji organoleptik terhadap tingkat penerimaan rasa dan aroma, namun tidak siginifikan terhadap warna dan tekstur es krim pisang batu. Panelis memberikan penilaian suka terhadap atribut rasa keempat perlakuan es krim pisang batu, sementara berdasarkan analisis statistik terdapat perbedaan rasa yang signifikan pada keempat perlakuan es krim pisang batu. Panelis mendeskripsikan suka terhadap rasa keempat perlakuan karena memiliki rasa pisang yang enak, manis, dan menyerupai susu. Perlakuan yang paling disukai panelis adalah ketika tepung pisang batu ditambahkan saat pendinginan karena dinilai lebih memilki rasa pisang yang lebih kuat.

Rasa manis yang yang dirasakan dapat berasal dari tepung pisang batu yang digunakan. Pisang batu mengandung inulin dimana merupakan komponen yang mampu memberikan rasa manis $10 \%$ lebih rendah dibandingkan gula. Peran inulin dalam memberikan rasa manis hampir sama dengan gula, memberikan rasa manis tanpa after taste karena mengandung molekul oligofruktosa rantai pendek. ${ }^{17}$ Selain itu gula yang ditambahkan juga memainkan peran penting dalam memberikan rasa manis pada es krim. Jumlah gula yang terkandung dalam semua perlakuan adalah sama.

Pada penilaian atribut aroma es krim pisang batu berdasarkan uji hedonik didapatkan hasil tingkat penerimaan keempat perlakuan es krim pisang batu adalah suka, sementara hasil analisis statistik menunjukkan terdapat perbedaan aroma yang signifikan pada es krim pisang batu. Aroma yang paling disukai panelis adalah aroma perlakuan yang memiliki kadar tepung pisang batu 12\% karena memiliki aroma campuran antara pisang kering dan aroma manis susu sapi.

Aroma suatu produk makanan adalah komponen sensorik yang dihasikan dari interaksi komponen pangan volatil yang terkandung di dalam bahan dasarnya dengan reseptor penciuman di rongga hidung. Aroma khas pisang disebabkan adanya kandungan pati yang terdegradasi waktu proses pengeringan pisang dan pemasakan adonan bahan es krim yang disubstitusi dengan tepung pisang. Saat degradasi kandungan pati terjadi perubahan yang ekstensif dengan eliminasi molekul air dan fragmentasi molekul gula di mana terjadi pemutusan ikatan karbon yang menghasilkan senyawa karbonil dan volatil sehingga menimbulkan aroma yang khas pisang kering. ${ }^{20}$ Aroma es krim juga diperkuat dengan aroma susu sapi yang merupakan salah satu bahan utama yang digunakan dalam pembuatan es krim. Peningkatan konsentrasi kadar tepung pisang batu yang diikuti dengan penurunan kadar susu bubuk membuat aroma pisang yang dirasakan lebih dominan sehingga menutupi aroma susu.

Berdasarkan hasil uji hedonik menurut panelis warna keempat perlakuan es krim pisang batu dapat diterima, cukup cerah, bagus serta menarik, dan berdasarkan hasil analisis statistik tidak terdapat perbedaan warna yang bermakna pada keempat perlakuan. Hal ini didasarkan pada deskripsi panelis yang menyebutkan bahwa semua perlakuan memiliki warna yang sama yaitu coklat dengan bintik hitam. Warna es krim yang agak kecoklatan ini berasal dari pisang batu yang mengalami reaksi pencoklatan ketika proses pengeringan sedangkan bintik hitam berasal dari biji pisang batu.

Reaksi pencoklatan (maillard) pada pisang batu terjadi karena adanya reaksi antara gula pereduksi dari karbohidrat pisang batu dengan gugus amino primer dari protein pisang batu. Reaksi maillard dapat terjadi pada suhu $35^{\circ} \mathrm{C}$, dan semakin cepat pada suhu $100^{\circ} \mathrm{C}$. Suhu yang digunakan dalam pembuatan tepung pisang batu adalah kisaran $33^{\circ} \mathrm{C}$ $36^{\circ} \mathrm{C}$ sehingga memungkinkan terjadinya reaksi maillard. Selain itu, selama proses pengeringan gula yang terkandung dalam pisang batu mengalami kontak dengan panas dan mengalami reaksi browning. ${ }^{16}$

Pada atribut tekstur didapat hasil uji mutu hedonik adalah suka dan tidak suka. Berdasarkan analisis statistik tidak terdapat perbedaan yang bermakna antara keempat perlakuan $(p>0,05)$. Meskipun demikian, rerata dari hasil uji hedonik menunjukkan bahwa panelis lebih menyukai 
perlakuan es krim dengan penambahan tepung pisang batu sebanyak 17\%. Menurut deskripsi panelis, panelis menyukai perlakuan tersebut karena hampir menyerupai tekstur es krim komersial, dalam hal ini tingkat kepadatan, kelembutan dan memiliki tekstur granula yang banyak seperti taburan oreo yang berasal dari tepung pisang batu.

Tekstur es krim dipengaruhi oleh komposisi bahan yang digunakan dan cara pengolahan es krim. Lemak dari susu berfungsi menghasilkan karakteristik tekstur yang lembut, membantu memberikan bentuk dan kepadatan, serta memberikan sifat meleleh yang baik. Penambahan tepung pisang batu dengan konsentrasi yang makin meningkat menyebabkan makin meningkatnya total padatan dari es krim sehingga tekstur es krim yang dihasilkan sedikit lebih padat, dan tekstur lebih berisi serta tidak berasa seperti gabus jika konsentrasi pisang lebih rendah akibat lebih banyak terbentuk foam. ${ }^{21}$

Selain itu kelembutan es krim pisang batu salah satunya berasal dari upaya untuk memperkecil partikel tepung pisang batu dengan melakukan pengayakan menggunakan ayakan 80 mesh sehingga menghasilkan ukuran partikel tepung yang halus yaitu sebesar $0,177 \mathrm{~mm}$.

Penilaian produk mempertimbangkan semua variabel yang berperan dalam menentukan mutu produk meliputi aktivitas antioksidan, kadar pati resisten dan uji organoleptik. Variabel dari segi gizi dan mutu organoleptik diberikan bobot yang sama oleh peneliti karena keduanya dinilai sebagai hal yang sama pentingnya untuk menentukan minat masyarakat terhadap sebuah produk pangan baru. Es krim dengan penambahan tepung pisang batu $17 \%$ dan ditambahkan saat pendinginan (BII) dipilih sebagai perlakuan terbaik walaupun dinilai sedikit kurang dari aspek tekstur. Tekstur yang dinilai sedikit kasar dapat diinovasi dengan melakukan dua kali proses pengayakan agar tepung lebih halus. Selain itu, pada perlakuan BII aktivitas antioksidan dan pati resisten yang cukup tinggi dibandingkan perlakuan yang lain. Aktivitas antioksidan pada es krim pisang batu masih tergolong rendah dengan persentase $<50 \%$ sedangkan untuk kandungan pati resisten sudah tergolong cukup tinggi dengan persentase $>10 \%$ sehingga es krim pisang batu dapat digolongkan menjadi pangan fungsional karena kandungan zat gizinya yang dapat menyehatkan kolon sehingga dapat mencegah penyakit kanker kolorektal.

\section{SIMPULAN}

Kadar antioksidan semakin meningkat seiring bertambahnya tepung pisang batu yang digunakan dan cara penambahan ketika pendinginan juga akan mengahasilkan aktivitas antioksidan yang lebih tinggi dari pada ketika pemasakan.

Perlu memperhatikan metode yang digunakan baik saat pengolahan yaitu pencampuran bahan yang homogen, waktu dan suhu pemasakan yang sama maupun pengujian agar mendapatkan hasil uji yang optimal dan cara pengeringan tepung pisang batu agar dapat mengetahui suhu yang dipakai secara pasti.

\section{DAFTAR PUSTAKA}

1. American Cancer Society."Colorectal Cancer Facts \& Figures 2014-2016". Diakses pada tanggal 19 juni 2018.

2. Kementrian Kesehatan Republik Indonesia. "Pedoman Nasional Pelayanan Kedokteran Kolorektal". Diakses pada tanggal 19 juni 2018. http://kanker.kemkes.go.id/guidelines/PNPKkol orektal.pdf

3. Shin S, Byun S, Park K, Moon T. Effect of Partial Acid Hydrolysis and Heat-moisture Treatment on Formation of Resistant Tuber Starch. Cereal Chem. 2004;81(2):194-8.

4. Sánchez E, Viuda M, Fernández J, Pérez JA. Resistant Starch as Functional Ingredient. Food Res Int [Internet]. 2010;43(4):931-42.

5. Purwani EY, Suhartono MT. Pati Resistan serta Perannya dalam Penghambatan Proliferasi dan Induksi Apoptosis Sel Kanker Kolorektal. Indones J Cancer. 2014;8(4).

6. Meutia YR. Pati Resisten: Strukur, Preparasi dan Efek Fisiologisnya. J Agro-Based Ind. 2010;27(1):72-84.

7. Ratnasari D, Rustanti N, Afifah DN. The Effects of Treatments on Batu Banana Flour and Percentage of Wheat Substitution on The Resistant Starch , In Vitro Starch Digestibility Content and Palatability of Cookies Made with Banana (Musa balbisiana colla) Flour. Earth Enviromental Sci. 2018;116.

8. Winarsi H. Antioksidan alami dan radikal bebas. Yogyakarta: Kanisius. 2007. Hal 25-27

9. Musita N. Kajian Kandungan dan Karakteristik Pati Resisten dari Berbagai Varietas Pisang. Teknol Ind dan Has Pertan]. 2009;14(1):68-79

10. Nandini VP, Siji S. Antioxidants and antioxidant activity common eight banana varieties in Kerala. International Journal of Advanced Engineering Research and Science.2017;(4)

11. Imam MZ, Akter S, Mazumder MEH, Rana MDS. Antioxidant activities of different parts of Musa sapientum L. ssp. sylvestris fruit. Journal of Applied Pharmaceutical Science.2011;01(10):68-72

12. Harianto $\mathrm{H}$, Thohari $\mathrm{I}, \mathrm{dan}$ Purwadi. Penambahan Tepung Porang (Amorphopallus 
onchoptllus) pada Es Krim Yoghurt ditinjau dari Sifat Fisik dan Total Bakteri Asam Laktat.[Skripsi]. Universitas Brawijaya. 2013

13. Rahmawati DP. Pengaruh waktu dan suhu penyimpanan terhadap aktivitas antioksidan ekstrak daun sembung. [Skripsi] UIN Syarif Hidayatullah Jakarta. 2017

14. Susrini. Index Efektifitas. Suatu Pemikiran Tentang Alternatif untuk Memilih Perlakuan Terbaik pada Penelitian Pangan Fakultas Peternakan. 3rd ed. Universitas Brawijaya Malang. 2015;40-45 p.

15. Mrmosanin JM, Pavlovic AN, Veljkovic JN. The Effect of Storage Temperature and Thermal Processing on Cathecins, Proyianidins and Total Flavonoid Stability in Comercially Available Cocoa Powder. Physics, Chemistry and Technology.2015;13(1):39-49

16. Tamanna N, Mahmood N. Food Processing and Maillard Reaction Products : Effect on Human Health and Nutrition. Int J Food Sci. 2015;2015.

17. Saeed M, Yasmin I, Pasha I, Randhawa MA, Khan MI. Potential Application of Inulin in Food Industry; A review. Pakistan Soc Food Sci Technol. 2015;25(3):110-6.

18. Sun J, Zhai W. Effect of Particle Size on Solubility, Dissolution Rate, and Oral Bioavailability: Evaluation using Coenzyme Q 10 as Naked Nanocrystals. Int J Nanomedicine. 2012;7:5733-44.

19. Rosida, Yulistiani R. Pengaruh Proses Pengolahan terhadap Kadar Pati Resisten Sukun (Artocarpus altilis). UPN Veteran Jawa Timur.2011
20. Arifin S. Studi Pembuatan Roti dengan Subtitusi Tepung Pisang Kepok. [Skripsi]. Fakultas Pertanian Universitas Hasanuddin.2011

21. Helen CDT, Sandriana JN dan Rumra M. Study on the Physicochemical and Organoleptic Properties of Tongka Langit Banana Ice Cream. AGRITEKNO Jurnal Teknologi Pertanian. Vol. 2016;5(2): 46-52.

22. Parwata IMOA, Wiwik SR, dan Raditya Y.Isolasi dan Uji Anti Radikal Bebas Minyak Atsiri pada Daun Sirih secara Spektroskopi Ultra Violet-Tampak. Jurnal Kimia.III (1):7-13

23. Goni I, Garcia-Diz L, Manas E, Saura-Calixto F. Analysis of Resistant Starch: A Method for Foods and Food Product. Food Chem. 1996;56(4):445-9.

24. Smith RA, Manassaram-Baptiste D, Brooks D, Cokkinides V, Doroshenk M, Saslow D, et al. Cancer screening in the United States, 2014: A review of current American Cancer Society guidelines and current issues in cancer screening. CA Cancer J Clin. 2014;64:30-51.

25. Chao A, Thun MJ, Connell CJ, McCullough ML, Jacobs EJ, Flanders WD, et al. Meat consumption and risk of colorectal cancer. JAMA 2005;293:172-82.

26. Cross AJ, Ferruci LM, Risch A, Graubard BI, Ward MH, Park Y, et al. A large prospective study of meat consumption and colorectal cancer risk: an investigation of potential mechanisms underlying this association.Cancer Res. 2010;70:2406-14. 